\title{
DÁIMON - GÊNIO OU DEMÔNIO?
}

\section{Tamar Rabelo de Castro*}

\section{RESUMO}

O objetivo primordial deste trabalho é investigar os elementos mistificadores da criatividade genial a partir do romance escrito por Thomas Mann, Doutor Fausto - A biografia do compositor Adrian Leverkühn narrada por um amigo. A criatividade aqui estudada não é relacionada ao perfil mediano do ser criativo, elemento que fornece versatilidade nos trabalhos cotidianos, mas sim a capacidade das "mentes brilhantes" que revolucionaram a forma de ver e interagir com os conhecimentos estabelecidos. Este artigo busca por em foco a relação do gênio criativo com o demoníaco, a partir da perspectiva da narrativa de ficção.

Palavras-chave: criatividade; genialidade; demonização; Fausto; ironia.

\section{ABSTRACT}

The main purpose of this work is to investigate the mystifying elements of the genial creativity through the romance written by Thomas Mann, "Doctor Faust - The Biography of the Musical Composer Adrian Leverkühn Narrated by a Friend". The creativity studied here is not related to the medium profile of the creative being, an element that offers versatility to daily works, but to the capacity of the "brilliant min$d s$ " that have revolutionized the way of seeing and interacting with the established knowledge. This article aims at focusing in the relation between the creative genius and the demoniac through the perspective of the narrative of fiction.

Key-words: creativity; geniality; demonization; Faust; irony.

\footnotetext{
* Tamar Rabelo de Castro é mestre em Teoria Literária pela UnB.
} 


\section{Cadernos Paranoá}

"Todo fazer criativo é refazer - e onde mãos criativas atuam há muito morrer e desaparecer.

E só isso é morrer e partir em pedaços? Sem dó nem piedade, o escultor bate no mármore.

Para libertar a imagem criativa de dentro da pedra, ele precisa ser sem piedade - por isso nós todos temos de sofrer e morrer e nos tornar pó.

Mas nós mesmos somos os escultores até mesmo a serviço do seu olho? Com freqüência nós mesmos trememos diante da criativa selvageria das nossas mãos." Friedrich Nietzsche

O romance Doutor Fausto, de Thomas Mann, é um intrincado de várias possibilidades interpretativas que coadunam com a magnitude da criação genial, mesmo que provida de questões aparentemente preconcebidas, remetendo a um mundo hermenêutico denso e conflitante. A obra desenvolve-se em vários eixos, valendo ressaltar alguns: a) a biografia de Adrian Leverkühn, feita pelo amigo Serenus Zeitblom, que se utiliza de sua amizade com a finalidade de criar um elo de comparação entre a criatividade genial de Adrian e a sua própria capacidade acadêmica; b) os elementos que constituem o criar e o desenvolvimento do processo de demonização da criação genial; c) a ligação entre as duas Guerras Mundiais e o espectro sombrio que se insere na sociedade, como conseqüência das mesmas; d) o gênio como ser desestruturante de um sistema pré-existente e criador de nova realidade a partir uma reorganização sistêmica; e) a ironia da existência a partir da visão nietzscheana do ser-acima-do-humano,' como elemento de superação de humanidade.

O enredo desse romance é o desenrolar da vida e obra de Adrian Leverkühn, compositor genial que cria uma teoria musical inovadora - a música dodecafônica, uma modalidade de composição musical que rompe com o estilo de composição tonal. Na música tonal, o compositor utiliza uma nota e gira em torno daquele tom, perseguindo a harmonia, como nos cantos gregorianos e nas composições sacras do barroco. 
Muitas inovações foram feitas no estilo de composição musical, como o cravo bem temperado, de Bach; no entanto, a harmonia tonal não é quebrada. A música dodecafônica, possível graças à afinação de Bach, ${ }^{2}$ permite nova forma de composição musical, utilizando, entre um tom harmônico e outro, os doze semitons da escala cromática, os quais são trabalhados de forma racional pelo compositor, não buscando a sensibilidade, mas uma representação lógico-matemática. De uma nota para outra, ouvem-se não apenas variações tonais, princípio básico da polifonia, mas um rompimento com a linearidade harmônica, o que faz com que o som pareça dissonante.

Essa música, num primeiro contato, seduz aqueles que não detêm conhecimento aprofundado desta arte, ao pensar na polifonia como quebra do conceito da música tonal. No entanto, não é assim que se processa. Uma música tonal pode muito bem ser polifônica, assim como um romance pode possuir esta característica das muitas vozes em consonância. Mas a música dodecafônica rompe plenamente com a consonância, sendo a dissonância o objetivo principal na produção de uma música racional e não sensitiva. Tal música quer falar ao cérebro e não ao coração.

A modalidade polifônica é fruto do pensamento moderno, enquanto a dodecafonia nasce da fragmentação inerente ao pensamento pós-moderno. As correntes filosóficas que lançaram a base do pensamento moderno ocidental trouxeram consigo a estrutura discursiva monologada ou dialogada, mas a evolução do pensamento humano é propulsora da ruptura com a linearidade, implementando a fragmentação do pensamento, abrindo caminho para a construção dodecafônica. Na música e na literatura, ocorrem fenômenos semelhantes, sendo que a polifonia serve às duas artes e a dodecafonia, sistema musical baseado na divisão da oitava em doze meios-tons, sem quaisquer relações tonais, serve à música.

Thomas Mann utiliza o princípio da música dodecafônica por ser uma composição que rompe com os padrões até então estabelecidos. Por representar a ruptura com a harmonia, sendo um exemplo 


\section{Cadernos Paranoá}

apropriado à problemática a que se lança: o enlace do homem criador com o demônio. Adrian Leverkühn é um homem de mente arguta, sequiosa de conhecimentos, que busca romper com toda a estrutura musical vigente. Mesmo que suas ações não sejam planejadas, no sentido de desconstruir todo um sistema musical, está implícito em seu fazer uma quebra de conceitos e teorias, transformando-o em um desestruturador da ordem estabelecida.

Thomas Mann coloca a capacidade criativa em três níveis. A capacidade mediana, na qual está incluída a maioria que busca resolver seus problemas diários e questões mais simples, representada pelo grupo de amigos de Adrian e Serenus; o acadêmico exemplar, que consegue enxergar coisas que estão além do universo de visão da média, Serenus, que supera seus pares - ele sempre soube do enlace do amigo com o diabo; e, num plano superior, estaria o gênio, o indivíduo com capacidade criativa superior à do acadêmico, representado pelo compositor genial Adrian Leverkühn, que tem coragem de romper com os conceitos para a criação de uma nova teoria musical.

Nesse romance, a genialidade reside na capacidade de ruptura, em que o gênio vê não só algo a mais a incrementar a ordem vigente, mas constrói o novo, a partir de bases antes não imaginadas. O que para ele se descortina como uma realidade clara a ser expressa, para o "mortal comum" é a visão aterradora de um salto no escuro, além da realidade. Os seres comuns contentam-se com o conforto da continuidade. $\mathrm{O}$ gênio é compelido obsessivamente à superação, posto que o existente não preenche sua necessidade de conhecimento.

Essa obra literária é uma alegoria da ruptura provocada pelo gênio e do estigma a que ele é submetido. Apresentando uma dose de loucura impressa na personalidade obstinada de Leverkühn, Serenus narra a fascinação do amigo pela música, pelo conhecimento, a forma como segue a "borboleta", veículo condutor do contato mefistofélico, e como se isola para construir sua obra, apontando para uma nova perspectiva de encarar a criação genial na literatura. 
Adrian Leverkühn, o personagem principal do romance Doutor Fausto, de Mann, é um compositor genial que produzirá uma nova teoria musical. Para tanto, faz um pacto com o diabo a fim de obter o "tempo genializado". Tal personagem é construído a partir de recortes da vida de Nietzsche, grande filósofo alemão que pregou a morte de Deus e anunciou o ser-acima-do-humano.

Desde a infância, Adrian sofre fortes crises de enxaqueca, que se intensificam após o contágio sifilítico, assemelhando-se à de Nietzsche, que aparentava sofrer de neurossífilis, doença degenerativa que provoca os seguintes sintomas: irritabilidade excessiva, cefaléia, insônia, alterações na fala e na visão, anormalidades pupilares e alterações nos reflexos profundos. A contaminação de ambos se deu em decorrência de suas ligações com prostitutas. Thomas Mann cria uma ligação entre o contágio venéreo e a facilidade criadora de Adrian, o que, de uma maneira mais estrita, torna-se uma ligação com o filósofo. Seria uma espécie de tentativa de localizar o cerne da criatividade?

Outro problema a ser levantado é a própria aparição de Mefisto como o cerne da criação genial. Se para criar algo novo o homem deve buscar auxílio nas forças do oponente divino, todo o conhecimento seria profano e, conseqüentemente, o homem-criador passa a ser um herético nigromante. Seria o gênio um ser espúrio, desumano? De onde nasceu a idéia de que quem produz conhecimentos é pactuário com as forças do mal? Seria a loucura de alguns gênios elemento mistificador de suas personalidades?

Thomas Mann atribui claramente à enfermidade, em seu romance, o status de potencializador do processo criativo do gênio. A dor é um elemento constante na vida de seu personagem principal, o compositor genial; a loucura o leva de encontro a Mefisto, sua mente precisa de auxílio para concretizar suas descobertas. Mas há algo além nessa personalidade perscrutadora, algo que não é facilmente decifrado por "mentes sãs". Isto é mefistofélico, por estar além do limite do entendimento da maioria. 
A genialidade é ainda um fenômeno cercado de mitos, apesar de várias pesquisas buscarem a chave para o mistério. Seria muito produtivo se alguém já tivesse sido capaz de desvendar a natureza da genialidade, bem como os elementos que fazem com que alguém se torne um gênio, pois a criatividade genial impulsiona o crescimento quando redimensiona o conhecimento.

Este trabalho não tem a pretensão de tentar descobrir a origem da criatividade genial, pois investiga o problema a partir da criação ficcional. Investiga os motivos que levaram à mistificação e conseqüente demonização dos indivíduos geniais. No romance de Thomas Mann, a criatividade assume uma relação com o universo mágico, mítico, sendo a loucura e o pacto com o demônio fontes de iluminação e propiciadoras da criação.

O romance Doutor Fausto proporciona ao leitor uma imensa viagem ao mundo da criatividade genial, da ruptura, por meio de um jogo interessantemente construído, a fim de ironizar a postura demonizadora do gênio e de sua produção.

O trabalho proposto, inserido nesse contexto, aponta para a ironia que subjaz à construção da narrativa. A abordagem irônica de um tema amplamente difundido na literatura e, por vezes, na ciência, assemelha-se à postura socrática, em que muitas vezes reconhecer a própria ignorância é a postura mais sábia. Dessa forma, quando o autor aparenta fechar a questão, abre as portas para uma visão além dos horizontes do romance, sendo necessário buscar bases na história, na psicologia e na filosofia, para que se possa iniciar a entrada no mistério que fecha as portas do romance.

\section{Elementos intrínsecos e extrínsecos da criatividade genial}

\section{Mente $\mathrm{x}$ cérebro}

Há alguns séculos, entender o funcionamento do cérebro era um mistério intransponível, mas com o avanço científico e tecnológico essa 
realidade vem aos poucos se modificando. Vários ramos da ciência têm buscado explicações para os fenômenos que envolvem o tão complexo órgão que domina o corpo e que é diretamente responsável pelas inúmeras sensações, emoções, percepções e produções artísticas, filosóficas, lingüísticas, entre outras. Os neurologistas iniciaram o processo de reconhecimento a partir da morfologia cerebral, identificando cada célula que compõe o cérebro e qual a função destinada a cada uma. A ciência já domina áreas complexas do tecido cerebral, apontando as zonas responsáveis por sono, fala, movimento, memória, etc.

No entanto, não basta entender os mecanismos de funcionamento do cérebro para que se tenha um domínio do que é a mente e de como ela funciona. O ser humano é dotado de sentimentos e percepções que vão além do simples mecanismo de células e ligações químicas que são produzidas nas regiões superiores do corpo. A distinção entre mente e cérebro é considerada importante por Steven Pinker, na obra Como a mente funciona. Segundo o autor, o cérebro seria o substrato fisiológico necessário para o desenvolvimento da mente, pois, sem os impulsos cerebrais primitivos, seria impossível ao indivíduo vivenciar as experiências, gerando percepções e juízos de valor, para os quais somente a mente humana tem se demonstrado capaz. Ao afirmar a diferença e ressaltar a importância do cérebro para a ciência, Pinker afirma:

[...] a mente não é o cérebro, e sim o que o cérebro faz, e nem mesmo é tudo o que ele faz, como metabolizar gordura e emitir calor.[...] O status especial do cérebro deve-se a uma coisa especial que ele faz, a qual nos permite ver, pensar, sentir, escolher e agir. ${ }^{3}$

Enfim, para entender a mente não basta estudar o cérebro como uma máquina engenhosamente desenvolvida, é necessário ir além. Freud deu alguns dos primeiros passos ao construir a teoria psicanalítica, desvendando alguns mistérios da mente: a complexa estrutura do inconsciente, suas relações subliminares com o subconsciente e a pequena parcela da mente que possibilita ao homem construir as 


\section{Cadernos Paranoá}

imagens de sua percepção consciente, mesmo que seja eivada de elementos subjacentes do inconsciente.

\section{A inteligência}

O termo inteligência passou a ser amplamente utilizado a partir das pesquisas de Galton, primo de Darwin, como resultado de pesquisas publicadas em 1869, no livro Hereditary Genius. A concepção de que a capacidade intelectual estava diretamente ligada a questões genéticas motivou tal trabalho, decorrendo daí a produção de testes com a finalidade de quantificar a inteligência do indivíduo.

Mais tarde, Binet cria um método de medição para selecionar crianças com necessidades de uma educação mais especializada para desenvolver e otimizar o aproveitamento educacional. No entanto, os hereditaristas, influenciados pela tese evolucionista de Darwin, passaram a utilizar os testes de medição do quociente de inteligência (QI) para distinguir pessoas "com maior potencial". Assim, começou uma corrida para provar que a inteligência poderia ser medida, como se fosse um elemento concreto e mensurável. Muitos psicólogos das décadas iniciais do século XX passaram a utilizar os testes para validação da qualificação dos indivíduos a partir de questionários, muito criticados em sua real eficácia, bem como pela ideologia racial em que se sustentavam.

Nesse sentido, a quantificação da inteligência acabou sendo mais valorizada do que a busca de entendimento dos processos pelos quais a mente passa no ato criador. Estava em voga um modismo eugênico que em muito se assemelhou aos ideais de Hitler, em sua tentativa de produzir uma raça superior.

Do início até meados do século XX, estudou-se a inteligência, mas a psicologia trabalhava sempre com métodos psicométricos. Mais tarde, os pesquisadores constataram a facilidade em burlar o resultado de tais testes. Respondê-los mais de uma vez, memorizando as questões, ou omitindo respostas, ou outras variantes subjetivas 
que, muitas vezes, não eram levadas em conta na hora da aplicação do exame, são exemplos claros das brechas percebidas nessas metodologias.

Partindo para a questão central deste trabalho, constatou-se outro problema com os testes de medida de capacidade intelectual quando aplicada aos indivíduos geniais. Seria o gênio um indivíduo "hiperdotado" em quociente de inteligência? Estaria a superdotação diretamente ligada à genialidade?

O problema que ora se interpõe torna-se mais complexo, pois ao buscar respostas a estas questões se obtiveram resultados conflitantes. Ao aferir o QI dos gênios do passado, não se teve uma certeza dos resultados dos testes. Algumas vezes, os resultados atestaram que possuir QI privilegiado não era suficiente para que o indivíduo produzisse uma descoberta inovadora. Em outras, que tal produção muitas vezes era proveniente do trabalho árduo do criador. Outro ponto controvertido é a rotulação. Seria Francis Galton, portador de um QI estimado em 200, no auge de sua criação, um gênio e Charles Darwin, seu primo, com 135 de QI, uma inteligência mediana?

Quando Terman usou pela primeira vez o teste do QI para selecionar um grupo de gênios infantis, ele inadvertidamente excluiu uma criança especial cujo QI não atingiu o número de pontos necessários. Algumas décadas mais tarde, aquele talento subestimado recebia o Prêmio Nobel de Física: Willian Shockley, o co-inventor do transistor. Ironicamente, nenhuma das mais de 1.500 crianças qualificadas segundo o seu critério de QI recebeu tão grande honraria quando adulto. ${ }^{4}$

A realidade dos fatos tem apontado para outra direção. O QI elevado é importante, facilita as ligações sinápticas. No entanto, não significa genialidade. $\mathrm{O}$ indivíduo genial pode ter superdotação, mas esta não é uma premissa invariável na formação do gênio. Visto que indivíduos "menos dotados" intelectualmente, segundo testes de QI, chegaram a descobertas que revolucionaram o mundo, enquanto outros com elevadíssimo potencial, aferido pelo mesmo método, fica- 
ram no limiar da produção acadêmica, e muitíssimos se perderam pela vida, sem um objetivo em que fixar seu potencial brilhantismo.

\section{A criatividade}

O avanço social, cultural e econômico do mundo pressupõe ações catalisadoras de mudanças. Nesse contexto, a criatividade tem sido um elemento subjacente que permeia as relações e interações do indivíduo com o outro e com o meio, agregando-lhe valorações identitárias que vinculam seu fazer, sua produção artística, cultural, econômica, social, religiosa, política, filosófica, tecnológica e científica, entre outros modos de produção que formam a sociedade num todo coeso.

As mais brilhantes culturas apresentaram um número modesto de indivíduos genialmente criativos que, por meio de suas produções, iluminaram a história das civilizações, contribuindo diretamente para o avanço tecnológico e científico experimentado pelo homem do século XXI:

As civilizações são freqüentemente definidas pela vida e pela obra de seus gênios criadores. A glória da Grécia Antiga foi construída a partir das realizações de Homero, Pitágoras, Heródoto, Sófocles, Platão, Hipócrates, Fídias e centenas de outros grandes criadores. A civilização européia moderna foi iluminada pelas obras similares de Galileu, Descartes, Tolstói, Rembrandt e Mozart. O mesmo pode-se dizer das outras civilizações. A história da Pérsia, da Índia, da China e de outras grandes civilizações é, em grande parte, formada de biografias de mentes notáveis dispostas cronologicamente. ${ }^{5}$

A civilização cristã ocidental, paradoxalmente fundamentada na liberdade de pensamento dos gênios gregos, a partir de um determinado ponto de sua história, cerceou a liberdade da produção criativa em prol da idéia de que o homem não poderia ousar ultrapassar os limites impostos, pois isso representaria um mergulho na soberba de postar o homem em um patamar próximo ao Criador. 
O racionalismo do século XVI apontava para a premência da desvinculação de fé e razão, conferindo às ciências autonomia e liberdade de atuação, libertando os pesquisadores do fardo do pecado contra as leis divinas. A fragmentação das ciências e a possibilidade de estudar a mente começam a delinear-se no século XVIII, aumentando o seu espaço com os estudos de Darwin e, posteriormente, de Sigmund Freud. Com o avanço científico e tecnológico, o século XIX viu a exacerbação dessa fragmentação, forçando o homem a ampliar o seu espaço de ação, conferindo-lhe ousadia para conhecer e desvendar mistérios antes proibidos por leis supostamente divinas.

Segundo Alencar \& Fleith, ainda não se tem uma definição que unifique as linhas de pesquisa a partir de uma visão mais concreta do que seja a criatividade, no entanto, sabe-se que ela não é diretamente proporcional ao quociente de inteligência.

Muitas são as definições propostas para o termo criatividade. Analisando-as, pode-se constatar que não há acordo quanto ao significado exato do termo nem consenso acerca da extensão em que essa habilidade se diferencia da inteligência, ou, pelo contrário, constitui uma faceta da inteligência que não tem sido avaliada tradicionalmente pelos testes de inteligência. ${ }^{6}$

Há uma discussão sobre a definição de inteligência e de criatividade e sobre a intrínseca relação existente entre ambos os conceitos. A partir da formulação dos testes de inteligência, tal prática tornou-se comum, para demonstrar as capacidades inatas do indivíduo, mas a premissa inicial desse método investigativo mostrou-se ineficiente, para resolver a questão de forma satisfatória, daí a necessidade da criação de novos enfoques da psicologia, para tentar elucidar o problema.

Alguns pesquisadores, como Guilford \& Torrance, têm tentado demonstrar, por meio de testes de criatividade, como se diferenciar o quociente de inteligência $(\mathrm{CI})$ da capacidade criativa. Desse modo, a criatividade passa a ser vista como um elemento a mais no processo 


\section{Cadernos Paranóá}

de intelecção e construção subjetiva e objetiva do mundo.

Alguns pesquisadores consideram que a criatividade é um constructo da inteligência; outros, que é um elemento dissociado que está ligado à inteligência. Atualmente, tem-se dado maior ênfase ao pensamento criativo, o qual, para a maior parte dos pesquisadores, deve ser incentivado e desenvolvido na maioria das pessoas.

Este trabalho trata mais especificamente da criatividade genial, e para tanto o recorte de criatividade utilizado é a capacidade que alguns indivíduos têm de utilizar suas forças na construção de algo brilhantemente original. Para conseguir tal façanha, esșas mentes precisam do pensamento divergente; assim, as brilhantes mentes geniais utilizam um outro processo de pensar o problema, que passa a ser enfocado de maneira diversa da maioria e por isso acabam encontrando soluções novas para problemas antigos ou criando novos patamares de saber.

\section{A genialidade}

A partir de constatações de que a capacidade intelectual não é inata, a ciência acredita que as mentes brilhantes são formadas por uma conjunção de fatores: altas habilidades, ambiente favorável à produção de pensamento divergente e bastante estimulação para que produzam resultados mais eficientes.

Não é tão-somente um alto índice de QI que indicará o bom desempenho do indivíduo superdotado. A questão vai além da simples meritocracia, como nas pesquisas de Galton e, posteriormente, dos hereditaristas. Muito ao contrário, esta corrida de aperfeiçoamento das espécies "à lá" evolucionistas acabou sendo apenas mais um elemento nas mãos de uma elite para delimitar capacidades e mentalidades.

Visto que o cérebro é apenas uma espécie de máquina, o que produz as dimensões do ser humano está além das ligações e impulsos neurológicos. Assim, para que o indivíduo superdotado seja cria- 
tivo e inovador, é necessário muito trabalho, materiais estimulativos, ambiente propício e liberdade de expressão. Não sendo, no entanto, tais fatores garantia de genialidade.

Para Simonton, analisando elementos mais palpáveis do ponto de vista científico, o gênio surge de um conjunto de fatores que se agregam: inteligência, curiosidade, capacidade de concentração e dedicação ao trabalho.

A própria necessidade de evolução da humanidade desencadeia fatos propícios a tais "espíritos livres", facilitando-lhes o acesso a campos ainda não explorados. $\mathrm{O}$ ambiente rico e estimulante a que estão submetidos acaba por levá-los a buscar novos caminhos. A curiosidade insaciável faz com que os gênios descubram outros horizontes a serem explorados. O seu aguçado intelecto auxilia no trabalho e, por fim, a capacidade de concentração e a dedicação com que se lançam ao trabalho árduo, muitas vezes de forma obsessiva. É possível observar indivíduos geniais trabalhando horas seguidas sem descanso, sem tirar um tempo suficiente para se alimentar, o que, segundo Aldous Huxley, provoca a reação no metabolismo que influencia na quebra das barreiras que limitam a percepção, fazendo com que pessoas submetidas a longos períodos sem alimentação sofram alucinações em diversos graus, sendo tais visões diretamente ligadas ao universo subjetivo individual.

Enfim, o gênio, segundo a maioria dos pesquisadores da criatividade, é aquele que possui um talento relevante e sabe utilizá-lo de forma produtiva, gerando obras de grande valor, catalisando modificações no meio em que está inserido. A superdotação intelectual, portanto, não pode ser tratada como sinônimo de genialidade, pois indica apenas um dado tipo de capacidade mental, enquanto a genialidade resulta de uma combinação de intelecto, condições sócio-econômico-culturais, motivação e trabalho quase obsessivo. 


\section{Cadernos Paranoá}

\section{A loucura e a genialidade}

Grande parte dos indivíduos geniais, segundo Simonton, em $A$ origem do gênio, possui uma dose de "loucura", gerando o epíteto de gênio-louco. O pesquisador afirma que a loucura completa é capaz de impedir o ciclo criativo, no entanto, o levantamento biográfico de muitos indivíduos, notadamente geniais, tem corroborado para que se difunda a idéia de que "sintomas que ficam a meio do caminho entre a personalidade normal e a anormal"7 propiciam a canalização do pensamento divergente, o que, com base em Huxley, facilitaria a quebra das barreiras da percepção, introduzindo-os em um universo onde as idéias divergentes podem ser domadas e utilizadas na construção de algo inovador.

É o estar em êxtase, lançar-se para dentro de si, numa busca de reconciliação consigo mesmo, havendo aí uma desvinculação da realidade. Seria como estar em "uma corda sobre o abismo; travessia perigosa, temerário caminhar, perigoso olhar para trás, perigoso tremer e parar"; 8 é o estado do homem que "sabe viver como que se extinguindo"; 9 é como se sua vida dependesse da criação. Nietzsche afirma: "O que me sustentou então? Sempre só a gravidez. E, toda a vez que a obra havia sido parida, minha vida pendia por um fino fio". ${ }^{10}$

Esse êxtase é irônico na sua concretização contrária à própria natureza do estado do extasiado; o êxtase é o que está fora, mas o gênio precisa de um mergulho nas profundezas de si mesmo. Nesse sentido, o êxtase é a força que conduz o gênio às esferas que estão fora da percepção dos demais.

Os pesquisadores sobre a criatividade e seu desenvolvimento não corroboram com as teorias que caracterizam os gênios como loucos. Tais teorias são calcadas no senso comum e em especulações que não possuem uma fundamentação teórica consistente, pois a lucidez é necessária para a identificação dos processos criativos e a utilização consciente dos conhecimentos para se chegar a descobertas inéditas. Ainda assim, é extensa a lista dos criadores geniais que apresentavam 
um certo grau de psicopatias. Simonton é um dos pesquisadores que apresenta uma lista, consideravelmente numerosa, de nomes de criadores geniais acometidos por algum tipo de distúrbio psíquico, tais como esquizofrenia grave, distúrbios de comportamento e distúrbios emocionais provocados por graves traumas.

A própria biografia de vários gênios concorre para a afirmação de que tais indivíduos apresentavam distúrbios orgânicos, como alguma degeneração cerebral, ou de ordem afetiva. Nietzsche, por exemplo, foi contaminado por uma espécie avançada da sífilis ou por um tumor que lhe atingiu o cérebro. Os pesquisadores da área de criatividade não têm ainda plena certeza se essas enfermidade são de fato propulsoras de percepções mais aguçadas, apesar da afirmação de Huxley, em sua obra As portas da percepção, que assinala serem as infecções, de toda sorte, ótimos estimulantes para a quebra das barreiras que limitam os sentidos, fazendo com que os indivíduos que padecem desses males tenham acesso a um mundo que não é permitido às pessoas "sãs".

Apesar de existirem controvérsias nas teorias sobre a criatividade, e como se dá a genialidade, a idéia de que o gênio caminha na fronteira entre a razão e a desrazão parece ser, no ponto de vista literário, uma das melhores fontes de luz sobre o processo criativo do gênio. Não que sua criação seja fruto de um distúrbio mental, mas por conseguir controle sobre suas crises.

Relatos de passagem da vida de vários indivíduos geniais, que contribuíram positivamente para o desenvolvimento da humanidade, seja na área tecnológica, seja nas artes, apresentam uma gama de relatos de atitudes pouco convencionais: Francisco Goya, pintor espanhol, tinha visões, posteriormente transformadas em quadros, muitos deles pintados na parede de sua residência; John Forbes Nash, matemático norte-americano, sofria de crises esquizofrênicas, vivia em um mundo irreal, mas descobriu uma forma de controlar suas crises, sendo que suas teorias foram construídas antes de se detectarem seus dis- 


\section{Cadernos Paranoá}

túrbios neurossistêmicos; Nietzsche, filósofo alemão, contradiz todo a civilização cristã e afirma a morte de Deus; no fim da vida, sofre sérias crises, sua doença se agrava lentamente, sendo que uma parte de seus escritos data da época em que alternava momentos de crise e lucidez.

A literatura busca nesses exemplos justificativa para a construção de seus personagens geniais; assim, surgem vários exemplos tais como: $O$ médico e o monstro; $O$ perfume; $O$ gênio indomável, bem como várias reconstruções cinematográficas da vida de autores como Goya, Gioto e John Nash. Caberiam vários outros exemplos, mas o objetivo de tal explanação é a análise da trajetória do personagem Adrian Leverkühn, no romance Doutor Fausto, de Thomas Mann, indivíduo maníaco, que sofre distúrbios neurossistêmicos e consegue, até certo tempo, controlar suas crises, transformando as visões que lhe aparecem, em seus momentos delirantes, em fonte de inspiração para a sua criação, usando sempre a loucura como sua maior aliada. No entanto, quando sua crise avança, sua produção é interrompida, sendo sua força criativa justificada por um suposto pacto com Mefistófeles.

\section{A demonização do conhecimento}

A formação da cultura ocidental, calcada no cristianismo, passou por um processo de inculcação de valores; vários mecanismos foram utilizados para a implantação do novo sistema. Algumas das armas amplamente utilizadas pela elite eram o medo, a figura do demônio, a domesticação pela demonização do conhecimento, uma vez que a história teogônica do cristianismo, quando descreve a queda e expulsão do homem do paraíso, acusa a serpente de oferecer ao homem o conhecimento proibido pelo Criador.

Essa relação direta entre o conhecimento e a serpente, símbolo do mal no sistema metafísico cristão, determinou por longos séculos o comportamento social, científico e tecnológico. O desenvolvimento 
das ciências abriu caminho para o trânsito livre do conhecimento, no entanto, os resquícios de elementos mistificadores ainda se presentificam na cultura ocidental. Nos séculos XX e XXI, o conhecimento adquire novas dimensões, novas abordagens, sendo visualizado como objetivo a ser alcançado pela ciência. Paradoxalmente, existem ainda mecanismos de controle na produção do saber, muitas vezes ditado pela subjetividade cristianizada de quem o produz. Assim, aquele que aponta caminhos inovadores, os quais fogem à esfera das linhas de abordagens específicas e tradicionais, é, às vezes, submetido a impiedosas discriminações.

Por outro lado, a busca pelo conhecimento, mola propulsora do desenvolvimento humano, tem se tornado um elemento demonizado pela tradição cristã, por desafiar o poder instituído. ${ }^{11}$ Muitas vezes, o saber torna-se traço de distinção no desenvolvimento social, trazendo a autonomia intelectual e, junto consigo, a luta contra a dominação. Surge, então, a pretensão, por parte de uma minoria, de reter o conhecimento mais questionador, que enseja mudança, pois tal tipo de conhecimento, aquele que é capaz de reestruturar sistemas, é perigoso no sentido de criar a possibilidade de divisão de poder, sendo altamente conveniente a manutenção da maioria na conformação de massa sem estrutura intelectual questionadora.

Só é permitido o saber trivial. Filosofar sobre o que todos sabem não é perigoso. $\mathrm{O}$ perigo começa a delinear-se quando um homem inicia um desenvolvimento de (des)construção do saber, que ultrapassa o limite do cotidiano, o limite do que é permitido a ele conhecer. Essa permissão é uma concessão do sistema dominante para socializar o conhecimento, mas não um tipo de conhecimento que garanta ao homem a faculdade de entender, pensar e questionar suas teias relacionais. No entanto, a maioria sente-se bem ao usar o "véu de maia", ${ }^{12}$ porque é melhor e mais confortante não ter conhecimento da amarga realidade: toda a estrutura vigente - social, religiosa, política - não passa de uma construção discursiva para a manutenção de uns poucos no poder. 


\section{Cadernos Paranoá}

Estar e permanecer no poder são objetos da cobiça dos "pobres mortais"; no entanto, tal cobiça torna-se pecado, ou seja, o desejo de estar no lugar dos poderosos é considerado luxúria, portanto, pecado capital. A massa deve contentar-se com sua posição de ovelha num rebanho guiado pelo pastor, detentor do poder conferido por Deus.

A luta pelo poder apresenta-se, mesmo que de um outro prisma, desde muito cedo, nas origens da tradição filosófica ocidental, alicerçada na tradição mitológica grega, bem como na transição do pensamento mitológico ao filosófico. $\mathrm{Na} \mathrm{mi-}$ tologia grega, o homem não tinha permissão para ter a chama sagrada, um dos símbolos da supremacia do Olimpo. Prometeu, o deus acusado de trair seus pares por conceder ao homem a pira sagrada, sofre severas punições, impingidas pelos próprios deuses, quando estes vislumbram o homem partícipe de seu conhecimento. O poder divino torna-se fragmentado, pois o homem que detém a chama é capaz de revolucionar e isso é perigoso para os deuses, pois pode fazer com que os senhores do Olimpo percam a sua primazia.

À medida que o conhecimento calcado na filosofia avança, o perigo da autonomia humana agiganta-se, intensificando-se quando o homem descobre que a origem de seu conhecimento está dentro de si e não no Monte Sagrado. Nesse caso, uma ameaça longínqua torna-se uma possibilidade real da perda da autonomia dos deuses, sinônimo de morte e representada pela falência do sistema de poder que converge para suas mãos.

O sentido demoníaco que se atribui ao Diabo cristão da Idade Média e do Renascimento, somando mitos e lendas à sua imagem, construindo uma criatura inequivocamente má, desprovida da essência de humanidade, está vinculado, de forma subliminar, à manutenção do poder. ${ }^{13}$ Os poderosos utilizam o medo como arma para forjar a hegemonia necessária para a institucionalização do mando, conferindo à divindade a autoridade e o poder, sendo eles mesmos a representação dessa divindade. 
Tal questão torna-se ainda mais complexa, na medida em que o mal encarnado em uma criatura metafísica passa a imperar em todos os níveis da estrutura social, transformando-se em suporte para a formulação de paradigmas que ensejam a continuidade do modelo medieval.

Cabe, como exemplo dessa continuidade do pensamento maniqueísta medieval em pleno século XXI, a constatação de que o mundo globalizado se vê frente à eminência de uma nova guerra mundial, cujos critérios não estão claros. Sabe-se apenas que o mundo está cada vez mais dividido maniqueisticamente. Existiria um diferencial entre a guerra que se anuncia neste início de século XXI das guerras do século XX, bem como das Cruzadas ou das guerras reformistas e contra-reformistas?

Apesar de todo o desenvolvimento tecnológico, científico e cultural, não há como afirmar a existência de uma diferença tão marcante quando a ideologia que prega a guerra está centrada na luta entre o Bem e o Mal. Tal questão passa a ser um fio condutor que interliga a ideologia da destruição do mais fraco, fazendo um intertexto cultural entre esta e outras guerras.

As guerras, em sua maioria, foram travadas com o objetivo de se aumentar o domínio espacial, em uma primeira instância, e econômico e tecnológico, numa leitura mais abrangente. Tais guerras são lutas armadas para apresentar maior ostentação do saber tecnológico, do saber aplicado ao "mal", no sentido da destruição e desmoronamento de sistemas sociais inteiros. Como conseqüência, ficam esfacelados, sem potencial para crescimento, mas tendo que, necessariamente, passar por uma lenta reconstrução. Algumas vezes, a reconstrução dura séculos de recapitulação de tudo o que foi produzido e há um demorado reerguer-se filosófico, sociológico, literário; em outras, há a destruição do que existia, e os vitoriosos contam sua história, num processo de sacralização desse ciclo maléfico.

Essa é a trajetória de formação do Estado alemão que, segundo Norbert Elias, em Os alemães, consolidou-se por meio de guerras, conflitos internos, que indubitavelmente foram fundantes de uma 


\section{Cadernos Paranoá}

cultura tipicamente alemã. Nesse sentido, a destruição e a reconstrução estão muito presentificadas no espírito teuto, sendo sua relação cultural provida das angústias existenciais geradas pelos extenuantes e constantes conflitos internos e externos. O espírito que permeia a obra-de-arte e a filosofia germânica é trágico e contestador, explicando, em parte, o surgimento de nomes como o do Nietzsche, Schumann, Kierkegaard, Beethoven, Wagner, entre tantos outros (des)contrutores e propiciadores de novos saberes.

O romance Doutor Fausto traz consigo a problemática da guerra como um elemento sombrio de destruição do sistema vigente. A narrativa se passa entre os períodos que compreendem as duas grandes guerras mundiais do século XX. A ligação entre a sinistra destruição, provocada pela guerra, e o desumanamente demoníaco, fica muito evidente num momento de destruição total de uma sociedade, onde todo o conhecimento produzido, representado pelas pessoas que o produzem, tenderia a ser desprezado ou banido. O conhecimento que sobrevive acaba sendo utilizado como forma de propaganda do vencedor.

Nesse sentido, o personagem principal da obra, Adrian Leverkühn, passa a ser uma alegoria do saber não institucionalizado. Para tanto, é desprovido de humanidade na medida em que é demonizado. Tal alegoria tem sua representação na construção maniqueísta dos líderes governamentais e espirituais, os quais fazem acreditar pela força e pela propagação do saber dos que desejam imperar soberanos, baseando-se na homogeneização de crenças a partir do medo, para construir um exército de sectários acéfalos. Tais seres se unirão na formação de uma maioria imbecilizada a ponto de perseguir a minoria que lhe apontar um novo caminho civilizatório. Tal maioria é a representação, em um sentido mais intrínseco, da condição de "humanidade", com a qual o gênio se vê incapaz de pactuar, por isso é visto pelos outros como ser excludente: o pactuário com as forças contrárias à constituição precípua desta "humanidade". 


\section{A construção irônica do discurso}

Todo discurso é impregnado de ideologia. Para romper com uma construção ideológica, faz-se necessária a construção de uma outra linha ideológica contrária, ou mesmo a aparente afirmação da ideologia vigente por meio da ironia. A ironia subverte a essência do discurso, conduzindo a um universo de negação interna, na medida em que aquilo que se afirma é refutado dentro da própria afirmação.

No discurso do romance Doutor Fausto, existe uma dissonância entre o discurso e a intencionalidade dos personagens, sendo a ironia a figura que medeia essa relação díspare, conferindo-lhe consonância. A própria afirmação constante de que a obra biográfica é real desconstrói-se. A dissonância entre a postura de Adrian e Serenus, longamente afirmada pelo biógrafo, conduz a uma consonância de posições: ou o narrador-biográfico não passa de inventor de casos, ou o compositor inventa um caso interessante para assustar o amigo. Assim, os personagens são conduzidos a esconder essa realidade - a criação da presença metafísica de Mefisto, fazendo com que tal presença repugnante seja inegável. Há um jogo de sombras, onde os personagens transitam entre pontos obscuros.

\section{Serenus e Leverkïhn}

Em primeira instância, há uma ligação entre Leverkühn e Serenus, ou seja, entre criador e criatura. No momento em que Serenus se coloca no papel de autor, cria a existência de Leverkühn. A ironia concretiza-se quando o autor constrói um narrador humanista cristão, o qual imprime suas ideologias na interpretação que faz da vida de Adrian.

\section{Serenus}

Leverkühn 


\section{Cadernos Paranoá}

Leverkühn não é apresentado de forma isenta; a apresentação biográfica é uma construção subjetiva que parte de Serenus. Alguns fatos são comprovados, mas a interpretação que é feita pelo narrador leva o leitor a acreditar que aquela exposição seja representativa da "verdade", ${ }^{14}$ ou seja, a existência do compositor Adrian Leverkühn é deslocada da ficção, como se tal compositor houvesse de fato passado pelo mundo dos vivos, não apenas pelo mundo dos personagens fictícios, os quais ganham vida a partir do trabalho de seu criador.

Como já foi dito, Serenus Zeitblom é um Professor Doutor em Filologia, humanista, católico. Tal ideologia o acompanha. Não há uma ruptura em Serenus, que se mantém fiel aos seus pré-conceitos, os quais influenciam até mesmo a sua escolha acadêmica. Leciona letras clássicas, voltando sempre ao medievalismo. Após ter seguido de perto todos os passos do amigo de infância, coloca-se no papel de salvaguarda da genialidade, representada pelo outro:

Adrian absolutamente não fazia questão de que eu me conservasse a seu lado, quando ele assistia aos cursos de Kumpf ou Schleppfuss, e até perdesse aulas do meu próprio programa. Agi assim por livre e espontânea vontade, unicamente inspirado pelo inelutável desejo de ouvir o que ele ouvia, de saber o que ele assimilava, numa palavra: de velar por ele - já que isso sempre se me afigurou extremamente necessário, ainda que em vão. O que tento expressar é uma mescla de sentimentos singularmente dolorosa: a mescla de urgência e inutilidade. Eu não ignorava que diante de mim se descortinava uma vida, que certamente poderia ser observada vigilantemente, mas nunca alterada nem influenciada, e no meu impulso de concentrar nela minha constante atenção havia muito do pressentimento que um dia talvez fosse minha incumbência prestar contas das impressões colhidas na juventude de Adrian. ${ }^{15}$

Essa é uma relação de consonância e dissonância que se junge no movimento de aproximação e distanciamento que acontece entre narrador - personagem principal - e autor. Enquanto narra o desenrolar da vida do amigo, Serenus deixa fatos de sua própria vida, impregnando a trama por uma ironia impressa na percepção de mundo 
captada por Serenus, voltada à repetição de conceitos, em detrimento da visão de Adrian, que produz novos universos significativos, a partir do rompimento com os conceitos.

Tal construção irônica traduz-se numa tensão entre os dois personagens. Serenus se afasta do amigo, quando apresenta uma diferença qualitativa; o outro lhe é superior, mas quer se aproximar, na tentativa de identificar-se com o outro, sublimando o valor de sua existência em detrimento da importância do outro. Há um jogo hierárquico construído pelo autor: Serenus é o acadêmico brilhante, mas não prova nenhuma teoria nova; Adrian é o criador, assim como Nietzsche, não necessita de mestres numa academia, mas recebe o título em decorrência de sua criação.

Sua proximidade de Adrian Leverkühn é muito mais profunda do que o simples elo de amigo de infância. Desde cedo, Serenus sabe da relação do amigo com os elementos demoníacos, tem consciência de que o riso do outro é demoníaco, tem certeza em alguns momentos, em outros, desconfia dos crimes que o amigo irá cometer, sente arrepios e tremores em suas mãos; recorrentemente, afirma que o destino do amigo tem ligações com os destinos da Alemanha e por fim que sua vida não teria sentido sem a existência do amigo e todo o seu percurso. Serenus identifica-se com Adrian a tal ponto que parece ser um desdobramento do outro.

\section{Leverkühn e Mefisto}

A ligação entre Leverkühn e Mefisto tem uma representatividade alegórica e irônica que ultrapassa a relação criativa, agregando valores a esta relação. Adrian não é genial porque fez pacto com o diabo, mas fez pacto com o diabo porque era genial.

Leverkühn

Mefisto 
A condição de ser-acima-do-humano é o que lhe permite ousar. As percepções do gênio são superiores às do acadêmico comum. Tal jogo, que é o estado de êxtase, leva-o a vislumbrar o fino fio que separa o bem e o mal, elevando-o à condição de senhor dos sistemas. E isso está impresso nas palavras de Mefisto, quando afirma para Adrian:

Eis o que nós percebemos muito cedo, e por isso, desde então, não te perdemos de vista. Vimos que teu caso merecia todo o nosso interesse, que havia nele possibilidades extremamente favoráveis. Bastaria que colocássemos embaixo dele um pouco do nosso fogo, que houvesse um levíssimo atiçamento, uma pequena provocação e a menor borracheira para transformá-lo em algo brilhante. ${ }^{16}$

Mefisto apenas impulsiona a percepção genial. Não é a sua essência. $\mathrm{O}$ cerne dessa capacidade é a própria natureza do gênio. Tal natureza transposta-se para um mundo metafísico, retira do humano a capacidade à genialidade.

\section{Serenus - Adrian - Mefisto}

A ligação do gênio criador com o demônio é decorrente da história da sociedade ocidental. A ironia impressa em Thomas Mann leva a uma linha interpretativa de redimensionar o poder criador. De onde vem a força criativa? Tal força não seria uma tensão entre o bem e o mal?

Serenus é um fraco que não assume o seu papel de criador. Esconde-se na sombra de cartas documentais, "talvez fictícias", para provar que sua obra é real. E, como tal, não constitui afrontamento ao divino, ou às forças dos poderosos nazistas, os quais podem destruí-lo se souberem-no criador de uma obra que discute a integridade desse sistema falido.

Nesse sentido, há um elo que une os três personagens, conferindo um elemento a mais na trama: a ligação entre Serenus - Mefisto - Adrian Leverkühn. A ligação de Adrian com Mefisto é conscien- 
te e desejada por sua mente fria e calculista, enquanto a ligação de Serenus é contida e reservada. Seu temor lhe põe em contato com Mefisto, quanto mais nega esta verdade, mais ela se torna aparente. Sob certa análise, a introdução de Mefisto na vida de Adrian talvez seja fruto apenas da imaginação católica de Serenus. Dessa forma, fecha-se um círculo entre os três personagens, nessa relação simbiótica da criação.

Tais ligações propiciam a formação de um triângulo. Assim, Serenus é posicionado como ponto central no vértice que aponta para cima, como se estivesse no comando da ação, como uma porta de entrada para o mistério. Os outros personagens se polarizam nos vértices inferiores dessa figura geométrica, sendo esta a ordem textual

Serenus

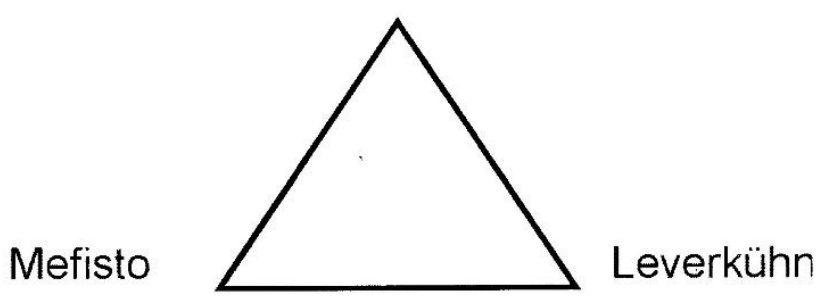

direta. É assim que o discurso do romance se apresenta, com o intuito de esconder uma relação subjacente a esta imagem aparente.

O triângulo principal fecha-se com seu traço firme, a partir das seguintes premissas:

1) Adrian ter condições de criar sua teoria musical, ele necessita de uma relação mefistofélica, da qual surge o pacto com o diabo.

2) Adrian segue o destino que se interpõe em seu caminho. Tenta desviar-se dele, assemelhando-se a Édipo. Mas quanto mais depressa tenta fugir do destino, optando pelo caminho da teologia, mais este o lança em direção à sua perdição, pois lhe dá os pressupostos de que necessita para conseguir 
fazer contato com Mefisto.

3) Mefisto é o cerne da criatividade.

4) Serenus afirma que não é criador, pois o ato de criar está intrinsecamente ligado ao tentador.

Assim, a relação está fechada, pois, se para criar algo novo é necessário, em primeira instância, o contato com o maligno e afrontar o mundo, Adrian é o único que consegue atingir tal estágio, pois Serenus afirma não ter aceitado durante toda a sua vida nenhum contato pessoal mais íntimo com o diabo, isentando-se do crime. No entanto, sua recorrente justificação demonstra um misto de curiosidade e vontade, refreadas por sua índole domada pelo catolicismo e pela vertente filosófica que adotou como parâmetro para seus comportamentos.

\section{Conclusão}

Este trabalho não tem a pretensão de propor uma resposta definitiva para a leitura do romance, nem para a questão do gênio. Em primeira instância, propor uma interpretação definitiva seria tentar conceituar a obra-de-arte e prendê-la a esquemas, fazendo com que ela perca sua aura artística; em segundo lugar, julgar resolver a problemática da genialidade por meio de uma obra de ficção, não seria a proposta mais adequada, pois estar-se-ia assumindo uma postura de generalização a partir de um único autor, postura perigosa para buscar validação de respostas a questões amplamente pesquisadas pelas ciências.

Conforme já foi mencionado anteriormente, este trabalho objetiva enfocar a problemática do gênio excluído e demonizado a partir da obra de Thomas Mann. Para tanto, o esquema interpretativo ora apresentado não enseja fechar outras possibilidades interpretativas, apenas lançar um olhar além da estrutura aparente montada a partir da relação metafísica e sua conseqüente desconstrução, a partir da ironia impressa no discurso desenvolvido no romance Doutor Fausto. 


\section{Projeção Virtual do Triângulo da Criatividade ${ }^{17}$}

A atividade criativa é aqui apresentada em suas várias nuances, aparecendo como um desdobramento da figura triangular inicial e formando um outro triângulo que aponta para a criatividade. Esta nova figura é inconscientemente virtual, estendendo-se num plano teórico. Assim como um iceberg que esconde sua realidade dimensional sob as águas oceânicas, a criatividade deixa perceber uma parcela muito pequena de sua superfície. O que está submerso, no obscuro universo do conhecimento, é muito maior do que a parte que se imagina esclarecida.

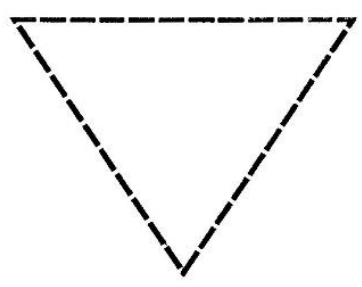

Criatividade

Esta figura aparece com linhas secionadas, por dar-se conta de que a genialidade não pode ser contida em uma dimensão tão estreita. A linha fechada não permitiria que, o que está contido neste espaço, fosse além de suas fronteiras. Sua virtualidade é um desdobramento não palpável, por não estar no universo físico, mensurável. Sua área de influência vai muito além das margens com as quais se queira delimitá-la.

A representatividade "demoníaca dessa esfera luminosa", em sentido estreito, seria uma visão reducionista desse elemento tão complexo. Acreditar que esta relação seja irônica e construída intencionalmente para apresentar o inominável sob uma forma perceptível e mensurável lança o olhar para uma dimensão que está além dos sentidos. Assim, o metafísico aparece como uma tentativa de denún- 


\section{Cadernos Paranoá}

cia direta da impotência de localizar o ponto exato da emanação da criatividade e da genialidade.

Da união entre os dois triângulos nasce a projeção de um losango capaz de produzir novas triangulações. O primeiro é aparente, representando como o problema é colocado no romance. Dele derivam sombras, as quais representam uma realidade não aparente, que só é possível acessar por meio da ironia impressa na construção da imagem aparente.

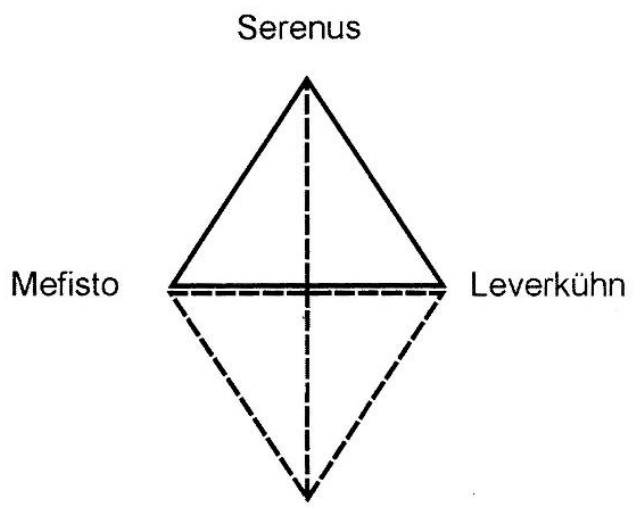

Demonização do gênio

Serenus tem uma relação indireta com Mefisto. No centro do discurso negador da consumação de uma relação transcendental, constrói-se a afirmação de que algo está errado na postura do biógrafo. $\mathrm{O}$ discurso do narrador está sempre afirmando sua personalidade nobre, isenta do crime e da subversão. Assim, o mero biógrafo pode esconder, por trás desse discurso, uma imagem grotesca. Não seria ele o inventor de Mefisto?

Essa é uma linha interpretativa que não pode ser descartada, visto que o demônio, como ente metafísico, portador do conhecimento criativo, é um mito construído por longos séculos, idéia com a qual compactuam os humanistas católicos, os quais não são capazes de se desprenderem da fé, na busca do conhecimento. A narrativa é fruto de uma visão ideologicamente influenciada. 
Vários elementos na postura do narrador-biográfico chamam a atenção para a sua integridade de biógrafo que relata apenas o que viu ou ouviu. Todos os fatos são narrados por Serenus, o qual afirma incontáveis vezes que sofre com a imagem grotesca, a qual se sente impelido a construir. A vida do biógrafo jamais se perpetuaria se não fosse pelo viés da vida do amigo. Ele sente uma ânsia de identificação com o gênio. Apesar de afirmar respeito por Adrian, seu biógrafo desloca a essência criativa para uma entidade metafísica. Tal força, colocada na perspectiva metafísica, retira do homem o mérito de sua criação. Ele afirma tantas vezes, reiteradamente, que o que faz é transcrever fatos, que acaba por levantar suspeitas sobre a veracidade de suas informações. Sua postura é por demais correta, quase um ser humano ideal que esta realidade acaba sendo minada.

Assim, Mefisto poderia ser um elemento inserido na vida de Adrian pelo seu biógrafo. Uma vez que a história somente é iniciada dois anos depois de sua morte, que se deu dois anos após a sua incapacidade mental, sendo que o biógrafo levou dez anos escrevendo seu relato, somam-se, assim, catorze anos de distanciamento entre os fatos e a provável publicação do relato.

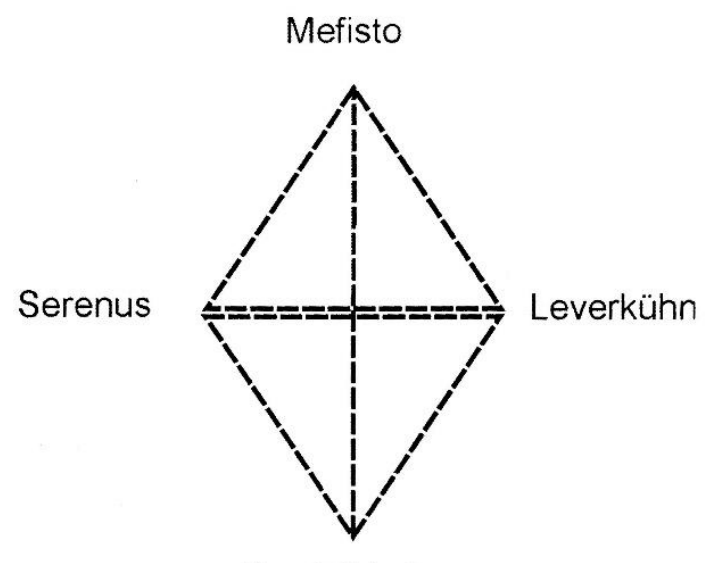

Genialidade 


\section{Cadernos Paranoá}

Tal inserção pode soar como uma explicação da genialidade restrita a uns poucos indivíduos. A justificativa que Serenus constrói para o fenômeno é mistificadora, apaziguando sua consciência por ter passado incógnito na vida.

Assim, na tentativa de encontrar tais respostas, por trás desse losango aparente, que é a construção discursiva da obra, subjaz uma sombra proveniente dessa mesma figura, na qual os personagens modificam suas forças. $O$ centro de influência passa a ser alocado na representação subjetiva de Serenus. Assim, Mefisto é superior ao gênio, pois o cerne da genialidade pertence a ele. Adrian busca tempo genializado que só pode ser encontrado na ampulheta de Mefisto.

Nesse jogo de forças, há uma outra leitura, se for levada em consideração que a confissão de Adrian - que afirma ter escrito a carta que documenta sua conversa com Mefisto, fato que será afirmado no fim da trama - não seja fruto da mente humanista de Serenus. Quando o compositor convoca a presença dos "amigos" para a execução de sua última peça - A Lamentação de Fausto -, confessa suas relações nigromantes com o espírito das trevas, afirmando que toda sua obra era fruto desse contato.

Leverkühn

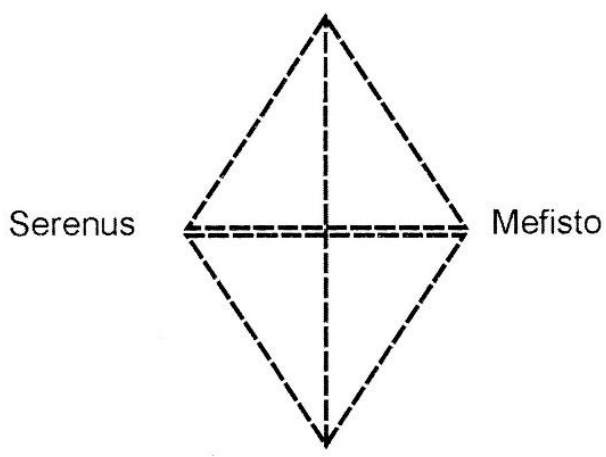

Criatividade genial 
Partindo do princípio da ironia, tal contato, narrado por Adrian, leva a duas linhas interpretativas, a saber: Mefisto figurase como uma projeção inconsciente do self do compositor que, no auge de sua doença, projeta as imagens de sua alucinação para fora de sua subjetividade. Apesar de desconfiar, no início, que Mefisto era produto de sua febre, acaba acreditando na existência desse ente; outra hipótese provável seria a consciência de Adrian durante todo o processo. Sabendo que Serenus acreditava nas forças demoníacas, constrói um documento a fim de persuadir o amigo que tais fatos ocorreram. Entrando num jogo, onde, de forma velada, elevaria o horror do amigo, rebaixando-o a partir de sua visão medivalesca, ou minimizaria, pra ambos, os efeitos de sua "loucura".

Assim, Leverkühn passa a ocupar o vértice superior do triangulo, rebaixando os outros personagens. Ao provocar em Serenus a ilusão do contato mefistofélico, Adrian supera-se em sua capacidade criadora genial, criando, inclusive, uma relação explicadora para a força que move a sua percepção além do limite normal.

No romance, a criatividade tem uma relação direta com Mefisto, afirmada pela ficção da obra, concretizando a ironia impressa nessa comunhão. Torna-se virtual, mormente quando é calcada no princípio da verossimilhança do compositor musical com o filósofo niilista ${ }^{18}$ que rompe com o cristianismo.

Nesse sentido, a criatividade genial é o ponto de divergência e convergência, a força motriz que provoca a projeção do triângulo principal e sua fragmentação em vários outros triângulos, levando sempre ao mesmo ponto de convergência: a genialidade.

Ao construir o personagem Serenus, Mann introduz uma voz irônica na obra. A imagem de Serenus afigura-se como uma espécie de consonância a partir da dissonância empregada pelo autor, o qual tira o máximo de consonância dos elementos completamente autônomos, aparentemente dispersos e dissonantes entre si, quer pela natureza de cada personagem, quer pela sua forma de agir no romance. 
O gênio busca o conhecimento. Conhecer o máximo é seu objetivo, ideologicamente representado pelos humanistas cristãos como sendo uma revolta contra o Todo Poderoso. Partindo do pressuposto de que o autor imprime sua ideologia na sua obra, a construção de um Filósofo Humanista Cristão é a crítica direta a este sistema de produção de seres alienados que, apesar de reconhecer que outro é o ser inquieto e que busca descobrir, prefere encobrir, por temer por sua alma. Serenus era a representação católica do Doutor em Filosofia e do humanista incorrigível que acreditava na salvação do ser humano.

Serenus se liga à genialidade a partir de sua admiração profunda por este fenômeno, personificado na figura de Adrian Leverkühn, mas se este não existisse, a essência de Serenus estaria esvaziada de sentido. Ao se colocar no papel de autor, assume as responsabilidades do destino de seus personagens, escondendo uma direção latente que é impulsionada indiretamente pelo autor verdadeiro. A criatividade genial de Thomas Mann fica evidenciada pela plena consciência do jogo paralelo que faz, enxergando de antemão a imagem grotesca que se delineia, por isso faz com que as mãos de Serenus tremam; o tremor das mãos de Serenus é a expressão do tremor interno de Thomas Mann.

\section{Notas}

1. 'O termo Übermensch tem sido traduzido como 'super-homem', o que é uma aberração, pois ele não deveria ser a repetição ampliada do homem, e sim sua total superação. Não basta, no entanto, corrigir para 'supra-homem' ou 'ultra-homem'. A definição se dá aí pelo masculino, o que não é garantia de nada. No original tem-se Mensch e não Mann. [...] Não se trata de uma divisão entre masculino e feminino. As mulheres não estão excluídas desses 'projeto religioso' de Nietzsche. [...] Esse projeto recai na tradição metafísica, como se fosse o palhaço de si mesmo, a negação de tudo o que critica. O Übermensch é a proposta de um ser-acima-do-humano, a ultrapassagem do ser humano através do ser humano. Seria sua transcendência, assim como o ser humano pretende ser a transcendência da natureza. É uma proposta, não um fato. O fato é que, como ideal que pretende ser pura negação, ele por si não nega nada, e tudo o que é negado não depende dele para ser afirmado. Tal seracima-do-humano é o novo deus da religião de Nietzsche. Faz dele, o antimetafísico, um autor metafísico. Não é um deus como o deus cristão, mas parece com ele na medida em 
que serve para negar todo o existente, afirmando o real homem histórico só como via de transição para esse novo ente (...)" (KOTHE, Flávio R., Prefácio da tradução de Fragmentos do Espólio, de Nietzsche, p. 10).

2 Afinação atribuída a Bach, mas alguns registros deixam entrever que tal descoberta foi resultado de discussões e trabalhos de um grupo de músicos (N. do O.).

3 PINKER, Steven. Como a mente funciona, p 35.

4 SIMONTON. A origem do gênio, p. 16.

5 SIMONTON. A origem do gênio, p. 13.

6 Id. op. cit., p. 13.

7 SIMONTON. A origem do gênio, p. 142.

8 NIETZSCHE, F. Assim falava Zaratustra, p. 11.

9 Id. ibidem.

10 NIETZSCHE. Fragmentos do espólio, p. 183.

11 Vide a querela entre o Criador e Lúcifer. Lúcifer - anjo de luz - torna-se demônio por ter lutado contra o poderio divino; seu intento era a divisão do poder - muito comum no sistema politeísta. Por causa de sua luta, é expulso da morada celeste, conseguindo a tão sonhada divisão de poderes: torna-se o Senhor do Mal e da Morte, em contraposição a Deus: Senhor do Bem e da Vida.

12 Véu de Maia: ilusão.

13 Não significa a inexistência de outras vinculações, no entanto, o trabalho, nesse momento, frisa mais enfaticamente esta linha de abordagem, por sua relação com a construção irônica que será demonstrada a posteriori.

14 Verdade colocada como fato, existência real em contraposição à existência ficcional. 15 MANN, Thomas. Doutor Fausto, p. 157-158.

16 MANN, Thomas. Doutor Fausto, p. 322.

17 A construção dessa figura virtual surgiu como uma sugestão do orientador, como uma representação gráfica do jogo de sombras, que é notado a partir da visualização da ironia no discurso do autor.

18 Referência a Nietzsche. 